\title{
NATIONAL CULTURE VALUES: REFLECTIONS ON FORMATION PROCESS OF FUTURE LEADERS IN INTERNATIONAL ECONOMIC COOPERATION
}

\author{
MARIJA NiKOLIC \\ mmarija.nnikolic@gmail.com \\ University Lum Jean Monnet, Italy \\ Maura La Torre \\ mauralatorre@yahoo.it \\ University LUM Jean Monnet, \\ Casamassima (Bari), Italy \& \\ University „G. d'Annunzio" of \\ Chieti-Pescara, Italy; \\ GORAN LaLIĆ \\ goranlalic88@gmail.com \\ University LUM Jean Monnet Bari
}

\begin{abstract}
The trend towards foreign investments in Serbia has been in rapid progress in recent years. The biggest and most valuable numbers of investments are coming from Italy. The authors' expectation is that the trend of Italian investments in future will continue; therefore it is of high importance for the representatives of both countries' business sectors to understand and accept differences and similarities to the other country's business culture. Research of cultural differences between two nations, which are considered like a frame of business culture, helps avoiding possible misunderstandings and improving business cooperation between two countries. Having in mind students of economics and management, on one hand like future leaders of Italian and Serbian business and on other like representatives of the current education value system in the field of economics and management, this study consists of an application of the 7-D Hofstede Model. The application of the model takes place through the administration of two surveys done by students of Serbian Megatrend University, in Belgrade, and Italian Università degli Studi Gabriele d'Annunzio, in Pescara.
\end{abstract}

Key words: national business cultures, Serbia-Italy economic future cooperation, influence of national culture values, next generation businessmen.

\section{INTRODUCTION}

Definition of the concept of culture is not easy. The extraordinary transversality of the term makes difficult any attempt to crystallize in precise definitions, constructs or theories. Over the years several theoretical contributions, have attempted to delineate the distinctive features, providing reference models for understanding the same.

From a socio-anthropological point of view, the concept of culture evokes the ancestral need for belonging and sharing and, at the same time, the ability to iden- 
tify the differences that make for uniqueness across a collection of individuals trained and mentally programmed in a certain way.

In this study, the analysis focuses on one of the different meanings of culture, that is the culture of a Nation in particular, on the verification of its possible influences on the process of formation of those who might become the next class leaders, able to work in organizations and the product of the understanding, assimilation and subsequent overcoming of differences between countries.

To do this, we have made the decision to apply a version of the well-known Hofstede's Seven Dimension model (1984, 1990, 2001, 2008), to compare the systems of cultural values of Italy and Serbia from the point of view of young people engaged in courses of study in economics and management, who live within the current context of training and preparation for the world of work and that these values are the subject inevitable influences.

Based on these considerations, this paper is structured as follows: first, a review of the main theoretical contributions on the subject; subsequently, the description of the research methodology, with clear indication of all seven dimensions predicted by the model; then, the elaboration and discussion of data obtained from the administration of questionnaires to Italian and Serbian students; and, finally, conclusive reflections of research.

\section{LITERATURE REVIEW}

As a first step in any intercultural research, the national culture concept and the Hofstede's model represent good start. A discussion on culture should first begin with a definition of the term. The number of different meaningful understandings of the term culture is very high; there were around 164 definitions collected until 1951. which Olie Rene discusses (Olie, 1995, p. 128). Geerd Hofstede also defines culture in various ways such as "a collective programming of the mind which distinguishes one group from another" (Hofstede, 1980, p. 25), "mental programming ...patterns of thinking and feeling and potential acting" (Hofstede, 1991a, p. 4). Also in $1991 \mathrm{G}$. Hofstede highlights that "culture is a collective phenomenon, because it is at least partly shared with people who live or lived within the same social environment, which is where it was learned". He continues explaining that culture is the training or collective programming of the mind that distinguishes the members of one group or category from another: it is a slow process defined by the social environment (Hofstede, \& Hofstede, 2005, p. 6).

In the research of Professor G. Hofstede, people are grouped by nationality; nevertheless, it is easier to define a group of people in a big group rather than study persons one by one. Since $1980 \mathrm{G}$. Hofstede was improving his research and today he differentiates national cultures according to seven bipolar dimensions: power distance, uncertainty avoidance, individualism/collectivism, masculinity/ femininity, long/short term orientation, indulgence/restraint and monumentalism/self-effacement.

Power distance explains the way a society handles inequality among its members. It is defined "as the extent to which the members of institutions" (family, 
school and community) "and organizations" (places of work) "within a country expect and accept that power is distributed unequally" (Hofstede, 1997, p. 28).

Individualism on the one side versus its opposite, Collectivism, as a societal, not an individual characteristic, is the degree to which people in a society are integrated into groups; "It describes the relationship between the individual and the collectivity that prevails in a given society" (Hofstede, 1980, p. 148). "Individualism pertains to societies in which the ties between individuals are loose: everyone is expected to look after himself or herself and his or her immediate family" (Hofstede, 1997, p. 51). In collectivist societies we find cultures in which people from birth onwards are integrated into strong, cohesive in-groups, often extended families that continue protecting them in exchange for unquestioning loyalty, and opposition to other groups.

Uncertainty avoidance is defined as "the extent to which the members of a culture feel threatened by uncertain and unknown situations" (Hofstede, 1997, p. 113). It indicates to what extent a culture programs its members to feel either uncomfortable or comfortable in unstructured situations. Uncertainty avoiding cultures try to minimize the possibility of such situations by strict behavioral codes, laws and rules, disapproval of deviant opinions.

Masculinity versus its opposite, Femininity, refers to the distribution of values between the genders which is another fundamental issue for any society, to which a range of solutions can be found. Masculinity stands for a society in which social gender roles are sharply differentiated. That is, men are supposed to be assertive, tough, focused on material success, etc., while women are supposed to be tender, concerned with quality of life, etc.

"Long-term or short-term orientation" is also known as Confucian dynamism. Long-term orientation characterizes cultures which place more importance on values associated with future orientation while short-term orientation cultures place more importance on values associated with past and present orientation.

For further research Hofstede included on an experimental basis Minkov's dimensions Indulgence versus Restraint and Monumentalism versus Flexumility (which he named Self-Effacement) [The Values Survey Module (VSM08) can be downloaded from www.geerthofstede.nl].

Indulgence versus Restraint became an entirely new dimension that will be described further. Indulgence versus Restraint is more or less complementary to Long-versus Short-Term Orientation; in fact it is weakly negatively correlated with it. It focuses on aspects not covered by the other five dimensions, but known from literature on "happiness research". Indulgence stands for a society that allows relatively free gratification of basic and natural human desires related to enjoying life and having fun. Restraint stands for a society that controls gratification of needs and regulates it by means of strict social norms.

Monumentalism versus Flexumility was significantly correlated with Short Term Orientation and less strongly with Power Distance, but G. Hofstede and Jang Hofstede decided to measure this dimension as an additional security. They replaced the creative label Flexumility by the more comprehensible label Self-Effacement. Monumentalism stands for a society which rewards people who are, 
metaphorically speaking, like monuments: proud and unchangeable. Its opposite pole, Self-Effacement, stands for a society which rewards humility and flexibility.

This powerful framework was used in the research of business cultures of Serbia and Italy to compare the systems of cultural values of the countries from the point of view of young people engaged in courses of study in economics and management which authors consider as future leaders of businesses.

\section{RESEARCH METHODOLOGY}

This paper analyzes the data obtained from the research of Italian and Serbian culture. The two cultures are compared following the seven dimensions of G. Hofstede's (1984; 1990; 2001; 2008), i.e. power distance, uncertainty avoidance, individualism/collectivism, masculinity/femininity, long/short term orientation, indulgence/restraint and monumentalism/self-effacement. A quantitative questionnaire was used as the research instrument; each of the cultural dimensions was measured by four items. The comparisons provide an insightful view of the differences and similarities of the two cultures.

The data for this study was obtained through two questionnaire survey forms (Serbian and Italian versions). This value survey module was recommended by G. Hofstede (2008) for future cross-cultural survey studies. The items included in the questionnaire for this study are shown in the Appendix. The original value survey module was in English; in our research Italian and Serbian versions were used. During the preparation of questionnaires back translation was adopted to ensure that translation problems concerning measurement scales are avoided. After revising the Serbian and Italian versions recommended by G. Hofstede the authors tested them on the colleagues in their universities who are research scholars and are bilingual. Then after revision Italian and Serbian versions of the questionnaire were translated back into English and compared with the English version of the questionnaire. After further discussions between authors, the two sets of questionnaire were finally completed. Through the above procedures, it is believed that the final version of the survey form is satisfactory in terms of similarity to the original English version.

Students from two universities, Serbian university Megatrend and Italian Università degli Studi G. d'Annunzio, were surveyed in this study. 20 respondents were Italian students of economics and management and 39 Serbian students from the same field. The questionnaires were collected immediately after the respondents had completed them. This ensured that all questionnaires were fully completed with no invalid responses. In each university, questionnaire distribution and data collection were performed by the authors with help of university employees.

A sampling issue that is well discussed in cross-national surveys is equivalence. As G. Hofstade highlights beside nationality "answers will also be influenced by other characteristics of the respondents, such as gender, age, level of education, occupation, kind of work, and year that the survey was held. Therefore, comparisons of countries should as far as possible be based on samples of respondents who are matched on all criteria other than nationality" (Manual VSM 94, p. 3). These two universities were chosen due to the contacts that authors have. Sam- 
ples for this study were selected based on the criteria of accessibility, functional equivalence, compatibility and representativeness. The samples in this study were functionally equivalent because all of the participants are students of economics and management and of similar age.

The data set shown below was based on 59 respondents from two universities, one Serbian University and one Italian University. From all participants approximately $44 \%$ are male. About $56 \%$ of the participants in both cultures are female. The average age for Serbian respondents on the survey was from 20-24 years old. The average age for the Italian participants was also from 20-24 years old.

\section{DATA ANALYSIS AND RESULTS}

In Table 1 we present the profile of our survey respondents. We have 39 respondents in Serbia and 20 in Italy. The number of respondents in Italy is lower than Serbia because of the procedure of giving questionnaires to the students. In both countries the number of female respondents is bigger than male respondents. In age structure we can see that in Serbia respondents are in the age group from 20-24 and in Italy beside that group, the group of more than 35 is also large.

Table 1. Profile of survey respondents.

\begin{tabular}{|l|c|c|}
\hline \multicolumn{1}{|c|}{ Profile of survey respondents } & Serbia & Italy \\
\hline Number of respondents & 39 & 20 \\
\hline Number of male respondents & 17 & 9 \\
\hline Number of female respondents & 22 & 11 \\
\hline Number of respondents under 20 years & 1 & 2 \\
\hline Number of respondents ranging between 20-24 years & 34 & 9 \\
\hline Number of respondents ranging between 25-29 years & 2 & 3 \\
\hline Number of respondents ranging between 30-34 years & 1 & 1 \\
\hline Number of respondents over 35 years & 1 & 5 \\
\hline
\end{tabular}

Source: Own research.

We calculate the seven dimensions of national value systems as components of national culture: Power Distance (large vs small), Individualism vs Collectivism, Masculinity vs Femininity, Uncertainty Avoidance (strong vs weak), Long vs Short-Term Orientation, Indulgence vs Restraint, and Monumentalism vs Self-Effacement. The calculation is based on the answers to the twenty-eight questions questionnaire.

Power Distance Index (PDI) is defined as "Power distance is the extent to which the less powerful members of organizations and institutions (like the family) accept and expect that power is distributed unequally" (Hofstede). The index formula for PDI is:

$$
\text { PDI }=35(\mathrm{~m} 07-\mathrm{m} 02)+25(\mathrm{~m} 23-\mathrm{m} 26)+\mathrm{C}(\mathrm{pd})
$$

in which $\mathrm{m} 02, \mathrm{~m} 07, \mathrm{~m} 23$ and $\mathrm{m} 26$ is the mean score for questions $02,07,23$ and 26 , the same is in formulas for other indexes. $\mathrm{C}(\mathrm{pd})$ is a constant (positive or negative) that 
depends on the nature of the samples; it does not affect the comparison between countries. It can be chosen by the user to shift her/his PDI scores to values between 0 and 100. The same is for others formula indexes. We choose to $C(p d)$ in this formula be 0 .

Table 2. Power Distance Index (PDI) values by country.

\begin{tabular}{|l|}
\hline Power Distance Index (PDI) values by country \\
\hline Country PDI \\
\hline Serbia 3,35 \\
\hline Italy 22,5 \\
\hline
\end{tabular}

Source: Own research.

The values in Table II show that the culture of Italy has a larger power distance than the culture of Serbia. This means in Italy, superiors and subordinates consider each other as unequal; the hierarchical system is felt to be based on some existential inequality; power is the basic fact of society that antedates good or evil and where its legitimacy is irrelevant; indigenous organizations centralize power more and subordinates are expected to be told what to do; and superiors are believed to be entitled to privileges in Italy.

According to G. Hofstede (1980), uncertainty avoidance measures the extent to which members of an organizational society feel threatened by and try to avoid future uncertainty or ambiguous situations. The index formula is:

$$
\mathrm{UAI}=40(\mathrm{~m} 20-\mathrm{m} 16)+25(\mathrm{~m} 24-\mathrm{m} 27)+\mathrm{C}(\text { ua })
$$

We choose to $\mathrm{C}($ ua) be 50 .

Table 3. Uncertainty Avoidance Index (UAI) values by country.

Uncertainty Avoidance Index (UAI) values by country

Country UAI

Serbia 4,3

Italy 18,75

Source: Own research.

The values in Table III show that Serbia has a low index value and Italy has a high index value. This means that in Serbia, people feel less threatened by ambiguous situations. Emotions are shown less in public. Younger people are trustworthy. People are willing to take risks in life. The authorities are there to serve the citizens. Conflicts and competition can be contained on the level of fair play and are used constructively.

According to G. Hofstede (1980), individualism describes the relationship between the individual and the collectivity which prevails in a given society. The index formula is:

$$
\mathrm{IDV}=35(\mathrm{~m} 04-\mathrm{m} 01)+35(\mathrm{~m} 09-\mathrm{m} 06)+\mathrm{C}(\mathrm{ic})
$$

We choose to $\mathrm{C}(\mathrm{ic})$ be 50 . 
Table 4. Individualism Index (IDV) values by country.

\begin{tabular}{|l|}
\hline Individualism Index (IDV) values by country \\
\hline Country IDV \\
\hline Serbia 25,85 \\
\hline Italy 48,25 \\
\hline
\end{tabular}

Source: Own research.

The IDV of Italy is higher than that of Serbia. This means people in Italy tend to think of themselves as "I" and tend to classify themselves and each other by individual characteristics, rather than by group membership.

Masculinity describes the extent of roles division between sexes to which people in a society put different emphasis on work goals and assertiveness as opposed to personal goals and nurture. The index formula is:

$$
\mathrm{MAS}=35(\mathrm{~m} 05-\mathrm{m} 03)+35(\mathrm{~m} 08-\mathrm{m} 10)+\mathrm{C}(\mathrm{mf})
$$

We choose to $\mathrm{C}(\mathrm{mf})$ be 0 .

Table 5. Masculinity Index (MAS) values by country.

\begin{tabular}{|l|}
\hline Masculinity Index (MAS) values by country \\
\hline Country MAS \\
\hline Serbia 17,5 \\
\hline Italy 26,25 \\
\hline
\end{tabular}

Source: Own research.

The MAS of Serbia is lower than that of Italy which means in Serbia, people show more concerns to personal goals (friendly atmosphere, getting along well with the boss and others, etc.).

Long Term Orientation stands for a society which fosters virtues oriented towards future rewards, in particular adaptation, perseverance and thrift. Short Term orientation stands for a society which fosters virtues related to the past and present, in particular respect for tradition, preservation of "face", and fulfilling social obligations. The index formula is:

$$
\mathrm{LTO}=40(\mathrm{~m} 18-\mathrm{m} 15)+25(\mathrm{~m} 28-\mathrm{m} 25)+\mathrm{C}(\mathrm{ls})
$$

We choose to $\mathrm{C}(\mathrm{ls})$ be 0 .

Table 6. Long Term Orientation Index (LTO) values by country.

\begin{tabular}{|l|}
\hline Long Term Orientation Index (LTO) values by country \\
\hline Country LTO \\
\hline Serbia 41,8 \\
\hline Italy 25,75 \\
\hline
\end{tabular}

Source: Own research. 
Serbia has a bigger index of long term orientation which means that society fosters virtues oriented towards future.

Indulgence stands for a society which allows relatively free gratification of some desires and feelings, especially those that have to do with leisure, merrymaking with friends, spending, consumption and sex. Its opposite pole, Restraint, stands for a society which controls such gratification, and where people feel less able to enjoy their lives. The index formula is:

$$
\mathrm{IVR}=35(\mathrm{~m} 12-\mathrm{m} 11)+40(\mathrm{~m} 19-\mathrm{m} 17)+\mathrm{C}(\mathrm{ir})
$$

We choose to C(ir) be 0 .

Table 7. Indulgence versus Restraint Index (IVR) values by country.

\begin{tabular}{|l|}
\hline Indulgence versus Restraint Index (IVR) values by country \\
\hline Country IVR \\
\hline Serbia 76,35 \\
\hline Italy 80,25 \\
\hline
\end{tabular}

Source: Own research.

Indulgence versus Restraint Index for Serbia and Italy is high and almost equal which allows relatively free gratification of some desires and feelings.

Monumentalism stands for a society which rewards people who are, metaphorically speaking, like monuments: proud and unchangeable. Its opposite pole, Self-Effacement, stands for a society which rewards humility and flexibility. The index formula is:

$\mathrm{MON}=35(\mathrm{~m} 14-\mathrm{m} 13)+25(\mathrm{~m} 22-\mathrm{m} 21)+\mathrm{C}(\mathrm{mo})$

We choose to $\mathrm{C}(\mathrm{mo})$ be 0 .

Table 8. Monumentalism Index (MON) values by country.

\begin{tabular}{|l|}
\hline Monumentalism Index (MON) values by country \\
\hline Country MON \\
\hline Serbia 62,45 \\
\hline Italy 9,25 \\
\hline
\end{tabular}

Source: Own research.

Serbia have higher MON Index than Italy which means that Serbia rewards people who are proud and unchangeable.

\section{CONCLUSIONS}

The Seven Dimensions of the model proposed by G. Hofstede return the vision of some particular cultural dynamics of the countries considered in this study. From the comparative analysis of the data extracted by the questionnaires admi- 
nistered to students Serbs and Italians, the differences between the two national cultures emerges with clarity, differences filtered by the experience of economics and management in young students.

Well, the system of values and components of national cultures, reveal substantial differences between Italy and Serbia as early as the first dimension predicted by the model.

The dimension of Power Distance indeed shows greater amplitude in the Italian culture: there will indeed be substantial centrality of power; a kind of power that is not always properly used by superiors, helps to increase the distance between them and the subordinates; a power due to unequal distribution of privileges between individuals should work together, establishing healthy relationships between leaders and subordinates guided by the dialogue and cooperation for a common good.

The other synthetic indicators, calculated for the remaining dimensions of national cultures, continue in the delineation of these differences, which emerge dimension after dimension, emphasizing the various connotations of the systems of cultural values, as seen through the lens of the students of the two universities involved in this study. In particular, the Uncertainty Avoidance Index (UAI), which measures the aversion of members of an organizational society against future uncertainty or ambiguous situations, shows that young people in Serbia are trustworthy, but hardly show their emotions in public and that the predisposition to take risks in life is supported by the active role of the institutions together with the ability to resolve conflicts and competitions in terms of fair play. The higher Individualism Index (IDV) in Italy than in Serbia highlights the tendency in Italy to emphasize the "I" $\mathrm{I}$ " so much so that people then are used to assess themselves and others through the meter of individual characteristics rather than on the basis of social group membership. The lower Masculinity Index (MAS) of Serbia demonstrates that there people show more concerns to personal goals as, for example, friendly atmosphere, getting along well with the boss and others, etc. If we then consider the measure of Long Term Orientation Index (LTO), expression of a society that promotes virtues such as adaptation, perseverance and thrift, we note the higher level of this in Serbia where, evidently, society fosters virtues oriented towards future. With regards, afterward, to the indicators that synthesize the last two dimensions of Hofstede model, ie Indulgence versus Restraint Index (IVR) and Monumentalism Index (MON), we denote, in the first case, a high value for both countries, indicating this a relatively free gratification of some desires and feelings; and about the second index, an higher value for Serbia, which means that this country rewards people who are proud and unchangeable.

Ultimately, considering the values system influence referred to this category of individuals, as well as representing the result of applying a theoretical model, it could become an established practice of the company towards a future of cooperation and integration, in which the students of today may become tomorrow's leaders, aware of cultural differences between nations, but ready to overcome objectives for collaboration, participation and sharing of results within organizations through the product of international economic cooperation. 


\section{REFERENCES}

Cassell, M. A. , \& Blake, R. J. (2011). Analysis of Hofstede's 5-D Model: The Implications of Conducting Business in Saudi Arabia. International Journal of Management \& Information Systems, 16(2), 151-160.

Christie, P. M. J., Kwon, I. G., Stoeberl, P. A., \& Baumhart, R. (2003). A Cross-Cultural Comparison of Ethical Attitudes of Business Managers: India, Korea and the United States. Journal of Business Ethics, 46(3), 263-287.

Ciambotti, M. (2001). L'influenza dei fattori culturali sul controllo manageriale [The influence of cultural factors on the managerial control]. Trieste: Lint Editoriale Associati.

De Luca, P., \& Vianelli, D. (2011). L'influenza delle variabili culturali sullo sviluppo del franchising internazionale: il caso italiano [The influence of cultural variables on the development of international franchising: the Italian case]. Sinergie rivista di studi e ricerche, 60(3), 145-161.

Harzing A.W., \& Ruysseveldt J.V. (Eds.). (1995). International Human Resource Management: an integrated approach (pp. 124-143). The Netherlands: Sage Publications.

Hofstede, G. (1980). Culture's Consequences: International differences in work related values. Beverly Hills: Sage Publications.

Hofstede, G. (1991a). Culture and Organisations. New York: McGraw-Hill.

Hofstede, G. (1997). Culture and Organizations: Software of the Mind. International Cooperation and its Importance for Survival. New York: McGraw-Hill.

Hofstede, G., Hofstede, G. J., \& Minkov, M. (2005). Cultures and organizations: Software of the mind. New York: McGraw-Hill.

Hofstede, G. (2009). Dimensionalizing Cultures: The Hofstede Model in Context. Online readings in psychology and culture, International Association for Cross-Cultural Psychology, 2(1). Retrieved from http:/ /dx.doi.org/10.9707/2307-0919.1014.

Jones, M. L. (2007). Hofstede - Culturally questionable?. Oxford. Oxford Business \& Economics Conference. Oxford 24-26 June, 2007.

Mariotti, S., \& Piscitello, L. (2007). Eterogeneità e competitività internazionale delle imprese [Heterogeneity and international competitiveness of enterprises]. Retrieved from http://www.fondazionemasi. it/UploadDocs/89_Mariotti.pdf.

Olie, R. (1995), The "culture" factor in personnel and organization policies. In: A. W. Harzing, \& J. V. Ruysseveldt (Eds.), International Human Resource Management: an integrated approach (pp. 124-143). The Netherlands: Sage Publications.

Pheng, L. S., \& Yuquan, S. (2002). An exploratory study of Hofstede's cross-cultural dimensions in construction projects. Management Decision, 40(1), 7-16.

Wu, M.Y. (2006). Hofstede's Cultural Dimensions 30 Years Later: A Study of Taiwan and the United States. Intercultural Communication Studies, 15, 33-42. 